\title{
VIRAL INFECTIOUS DISEASES IN DOGS IN THE VETERINARY HOSPITAL OF FEDERAL UNIVERSITY OF PARANÁ (PERIOD 2000-2001)
}

FRANCO, M.B ${ }^{1}$.; HAMANN, W $^{2}$.; FERRARI, M.V ${ }^{2}$. ;BRITO, H.F.V. ${ }^{1}$.; KASECKER, G.G ${ }^{1}$.; PERRONI, M.A ${ }^{1}$.; SINCERO, P.C. ${ }^{1}$; TRANQUILIN, M.V. ${ }^{1}$; WERNER, J. ${ }^{1}$

${ }^{1}$ Curso de Pós-Graduação em Ciências Veterinárias, UFPR;

${ }^{2}$ Departamento de Medicina Veterinária, UFPR.

Viral infectious diseases continue to be an important daily concern in small animal practice, especially due to its acute onset and easy transmissibility with high morbidity and mortality, more frequently in puppies. The diagnosis is usually based on anamnesis, clinical signs and minimum database (complete blood count, creatinine, urea, TGP, TGO). Most efficient methods with high sensibility and specificity are not often utilized in routine, like ELISA, PCR, eletronic microscopy and others. In the Veterinary Hospital of UFPR between 01/02/2000 and 28/02/2001 there were 3154 new cases, of which $233(7,4 \%)$ were suspected of viral infections. A total of 59 cases $(25,3 \%)$ were Canine Distemper Virus, 157 cases $(67,4 \%)$ were viral gastroenteritis (Canine Parvovirus and Coronavirus), 12 cases $(5,2 \%)$ were Infectious Laryngitis (Adenovirus type 2 ) and 5 cases $(2,1 \%)$ were Canine Infectious Hepatitis (Adenovirus type 1). The age of the dogs vary from about 35 days to 7 years, but most of the cases were of puppies. In this study, 114 cases $(49 \%)$ were in puppies from 35 days to 3 months of age, 81 cases $(34,7 \%)$ in dogs from 3 months to 6 months of age, 28 cases $(12,2 \%)$ in dogs from 6 months to 2 years of age and 10 cases $(4,1 \%)$ in dogs with more than 2 years of age. Among these 233 dogs there were 137 males $(58,8 \%)$ and 96 females $(41,2 \%)$. 82 dogs $(35,3 \%)$ had no breed, 32 dogs $(13,7 \%)$ were Rottweillers, 27 dogs $(11,7 \%)$ were Poodles, 23 dogs $(9,8 \%)$ were Dachshunds and 69 dogs $(29,5 \%)$ were from other breeds. The general mortality is about $30 \%$, being 9 cases of viral gastroenteritis $(5,7 \%), 6$ cases of Canine Distemper Virus $(10 \%)$, no case from Infectious Laryngitis and 4 cases of Canine Infectious Hepatitis (80\%). The best approach to these diseases is prevention, with orientation to the owners and vaccination, more effective diagnosis and more studies about the efficacy of treatments for each disease.

Key Words: dogs, viral infectious diseases. 